\title{
Rubella screening and immunization of schoolgirls: a long-term evaluation
}

\author{
HELEN ZEALLEY* \\ Regional Virus Laboratory, City Hospital, Edinburgh
}

\begin{abstract}
SUMMARY
A three-year rubella immunization programme is described in which 9,231 Edinburgh schoolgirls were screened for rubella antibodies. Of these girls $2,519(27 \cdot 3 \%)$ were found to have rubella HAI titres of $<32$, and 2,258 were immunized with either Cendehill or RA27/3 rubella vaccine. Of those who were immunized, $99 \%$ were found to have detectable HAI antibody two months later.

From the first cohort (born in 1956) 1,072 girls have been enrolled in a 20 -year programme to study the long-term value of these rubella vaccine strains; 536 of these girls had an initial HAI titre of $<32$ and were immunized with rubella vaccine or remained at risk because they refused immunization. Each girl has been paired with another who was found to be immune by natural infection. Of the 1,072 girls concerned, $1,031(96 \%)$ remained in the programme at the end of the first year. Further serological tests at this time showed that $93 \%$ of all girls had HAI titres that were either stable or within a twofold variation of the previous sample.
\end{abstract}

\section{INTRODUCTION}

Since the first isolation of rubella virus (Parkman, Buescher, and Artenstein, 1962; Weller and Neva, 1962) several serological tests of immunity to this virus have been developed. The widely used haemagglutination-inhibiting antibody (HAI) test (Stewart $e t$ al., 1967; Dold and Northrop, 1968) can measure long-term immunity to rubella in whole populations and in individual women of child-bearing age.

Epidemiological surveys have confirmed that rubella is endemic in most large communities, and this allows natural immunization to occur in up to $85 \%$ of the population by the age of 15 years: despite this high level of herd immunity, extensive outbreaks still occur which increase the risk of

* Formerly Registrar, Regional Virus Laboratory, City Hospital, Edinburgh. Present Address: Fellow in Community Medicine, South-Eastern Regional Hospital Board, 11 Drumsheugh Gardens, Edinburgh. infection in non-immune women of child-bearing $\vec{\omega}$ age (Horstmann, 1971).

The cultivation of strains of rubella virus has $\stackrel{\odot}{\stackrel{\circ}{\circ}}$ also made it possible to attenuate a number of these $i$ for use in vaccines. Much work has been done on $\stackrel{\oplus}{\rightarrow}$ vaccine development and the safety aspects of three in particular strains, Cendehill (Martin du Pan,, Huygelen, Peetermans, and Prinzie, 1968), HPV-77 (Meyer, Parkman, and Panos, 1966), and RA 27/3 (Plotkin, Farquhar, Katz, and Ingalls, 1967). All 8 have been reported to fulfill McCarthy's criteria (McCarthy and Taylor-Robinson, 1967) and are $\frac{\hat{2}}{2}$ now in use in different parts of the world. Studies of $\vec{c}$ vaccinated persons one (Fogel, Moshkowitz, Rab non, and Gerichter, 1971; Marshall et al., 1971, two (Prinzie et al., 1969; Hillary, 1971), and thre (Meyer et al., 1969; Buser and Nicolas, 1971) years after immunization have shown that vaccineinduced antibody titres may continue to increase $\stackrel{\circ}{\circ}$ between two and 12 months following immunization $\stackrel{\perp}{\perp}$ (Fogel et al., 1971; Marshall et al., 1971) and that $\overrightarrow{\vec{B}}$ antibodies stimulated by vaccine strains are lost 3 more rapidly than those acquired by natural rubella infection (Buser and Nicolas, 1971). In one report further antibody follow-up studies are proposed but the numbers involved are small (Fogel et al., 1971).

National policies for administration of rubella $\stackrel{3}{.}$. vaccines differ. In the United States of America an attempt is being made to prevent the spread of $₹$ rubella virus in the community by widespreado immunization of prepubertal children, that is, those most likely to introduce infection to a pregnanto woman (Enders, 1970). European policy concentrates on the future child-bearing population byo extensive immunization of young adolescent girls $N$ through subcutaneous administration of Cendehill and RA 27/3 vaccine. The efficacy of this policyo will depend largely on the length of time that artificially induced immunity to rubella can persist.

Marshall and his colleagues (1971) mention a? screening programme which preceded the immuniza- $T$ tion of susceptible girls in certain selected schools. 
This procedure has not been widely adopted because of the anticipated limitations of laboratory services; thus, as adults, most vaccinated children may remain in doubt as to whether their primary infection was with naturally circulating virus or with an attenuated strain.

The need for long-term evaluation of vaccination programmes was emphasized by Horstmann (1971) when she was referring to the American policy of protecting women in the childbearing years by raising the level of herd immunity. The present report describes the feasibility of a programme which included screening for HAI antibody of all girls aged 13-14 years under the care of one Local Education Authority, and immunization of those girls who lacked satisfactory naturally induced immunity. Susceptible girls from the first cohort (born in 1956) who required rubella vaccine, and a similar number of girls from the same schools with immunity to rubella acquired by natural infection, were enrolled in a 20-year follow-up programme. A comparison is to be made of their persisting rubella serum antibody titres, the incidence of clinical rubella, and ultimately the health of their children. This report describes the results from the first year of this programme.

\section{SELECTION OF SchOolgirls}

During the period 1970-72, forms giving information about rubella and its control were sent to the parents of every girl in her 14th year at all Edinburgh secondary schools, with one minor exception. The parents were offered a finger-prick blood test for their daughter in a screening programme for rubella HAI antibodies. Only those girls who were seronegative or who had low, and possibly nonspecific $(<32)$, HAI antibody titres were then immunized. The response of the immunized girls was examined by a further blood test two months after immunization, at which time it was also possible to enquire about side effects of immunization. Before immunization and at follow-up, each girl was asked the date of her latest menstrual period. When menstrual irregularity was reported, further enquiry was made as to the possibility of pregnancy.

In order to investigate the effect of this vaccination, girls vaccinated in the first year of the study only were also invited to take part in a long-term evaluation. In addition to those vaccinated, an equal number of girls who had acquired immunity by natural infection were invited to join the group. The naturally immune girls were selected from the same schools, and their names were adjacent on the school list to those who were found to require vaccination. Because of the pattern of secondary education in Edinburgh this was assumed to give good matching for socio-economic status but no attempt was made to match the girls for family size.

\section{Maintenance of Contact with the Follow-uP GiRLS}

Annual contact with all the girls is made, at the appropriate time, by sending a returnable questionnaire enclosed with a birthday card. As well as details of any alteration in a girl's name and address, the questionnaire asks for information relevant to any aspect of rubella in the previous year and, where applicable, a very brief obstetric history. Up to eight reminders are sent to girls not responding immediately and, where necessary, attempts are made to trace girls who have moved house by contact with neighbours, the general practitioner, the local medical Executive Council, and the Central Register.

\section{Collection of Follow-up Serological SPECIMENS}

After the initial tests further blood specimens will be obtained at intervals of five years until the girls have reached the age of 35 years. In order to make additional personal contact with the girls $b$ fore they left school the first set of follow-up blood tests was taken in the summer term 1971, one year after vaccination of the seronegative girls. (Girls who had left Edinburgh were asked to send in a sample of blood taken by their new general practitioner). It is proposed to collect future samples in the following ways:

(1) at social reunions in the girls' old schools;

(2) at evening sessions in a central Edinburgh clinic;

(3) by home visits, where necessary;

(4) by contacting out-of-town general practitioners.

It is hoped that at least $50 \%$ of both main groups of girls will remain in the programme until the age of 35.

\section{Materials AND Method}

\section{Collection and Preparation of Sera}

For screening and post-vaccination tests approximately $0.2 \mathrm{ml}$ of whole blood was collected into labelled glass agglutination tubes $\left(2 \times 1 \frac{1}{4}\right.$ in) from a thumb prick. Serum, $0.1 \mathrm{ml}$, was removed from each tube after centrifugation at $2,000 \mathrm{rev} / \mathrm{min}$ for 
10 minutes and mixed with $0.3 \mathrm{ml}$ of dextrose gelatin veronal buffer (DGV) containing manganous chloride and heparin (Dold and Northrop, 1968). The one-year follow-up serum was obtained from venous blood and was treated in the same way. After 20 minutes at $4^{\circ} \mathrm{C}$, a drop of $50 \%$ suspension of day-old chick cells in DGV buffer was added before the mixture was left overnight at $4^{\circ} \mathrm{C}$. The next day, after further centrifugation at $2,000 \mathrm{rev} /$ min for 10 minutes, the supernatant (now at a serum dilution of $1: 4$ ) was removed and inactivated at $56^{\circ} \mathrm{C}$ for 30 minutes.

The HAI test was based on the method of Stewart and his colleagues (1967). All sera were titrated in twofold steps in DGV from dilutions of $1: 8$ to 1 : 256. Rubella HA antigen (Flow Laboratories and Standards Laboratory, Colindale) was titrated in the presence of a $0.2 \%$ suspension of day-old chick cells on the morning of the test and was used at a concentration of four haemagglutinating units. The mixture of equal parts of serum and antigen was allowed to stand for 60 minutes at room temperature before the addition of the $0.2 \%$ suspension of day-old chick cells. Serum, antigen, and cell controls were included in every batch of tests. The tests were read after 90 minutes at $4^{\circ} \mathrm{C}$ and the highest dilution of serum causing complete inhibition of agglutination was taken as the end point.

Follow-up blood tests (post-immunization and one-year follow-up) were always tested in parallel with that girl's previous specimen, which had been stored at $-20^{\circ} \mathrm{C}$ in its treated form.

\section{VACCINES}

Two preparations of rubella vaccine were used, Cendehill, prepared in primary rabbit kidney cell culture, and RA 27/3, prepared in human diploid cells. Both vaccines were used at random in all schools, and reconstituted with $0.5 \mathrm{ml}$ of sterile diluent immediately before subcutaneous inoculation with disposable Mantoux syringes.

\section{REPORTS}

All parents and general practitioners of the girls taking part were sent the results on their daughters and patients respectively. They were informed whether the girl now had natural or artificially induced immunity to rubella.

\section{RESULTS}

\section{SCReening and Immunization Programme}

Girls born in 1956, 1957, and 1958 have now been offered screening and subsequent immunization where this was shown to be necessary. The numbers
TABLE I

NUMBER OF GIRLS OFFERED HAI SCREENING TEST NUMBER TESTED, AND NUMBER IMMUNIZED

\begin{tabular}{|c|c|c|c|c|c|}
\hline \multirow{2}{*}{\multicolumn{2}{|c|}{$\begin{array}{l}\text { HAI Screening } \\
\text { Test }\end{array}$}} & \multicolumn{3}{|c|}{ Year of Birth } & \multirow[b]{2}{*}{ Total } \\
\hline & & 1956 & 1957 & 1958 & \\
\hline Offered & $\ldots$ & 3,219 & 3,894 & 3,909 & \multirow{5}{*}{\begin{tabular}{l}
\multicolumn{1}{c}{11,022} \\
$114=1 \cdot 0 \%$ of \\
number offered \\
$9,231=83 \cdot 8 \%$ of \\
number offered \\
$2,519=27 \cdot 3 \%$ of \\
number tested \\
$2,258=24 \cdot 5 \%$ of \\
number tested
\end{tabular}} \\
\hline Refused & . & 18 & 54 & 42 & \\
\hline Given & . & 2,679 & 3,262 & 3,290 & \\
\hline Titre $<32$ & . & 601 & 983 & 925 & \\
\hline Immunized & $\ldots$ & 519 & 892 & 847 & \\
\hline
\end{tabular}

offered the test, actually tested, and immunized are shown in Table I. Only 114 girls (1\%) of the 11,022 girls offered the screening test refused to participate, but 1,677 girls $(15 \%)$ were absent from school on the days of blood sample collection or of immunization. When this occurred, the girls have been added to the cohort tested in the subsequent year. No distinction has been made between girls from different schools or from families of differing size or socio-economic background.

Although some correlation between the rubella HAI antibody titres and a history of clinical rubellas was found, quite a high proportion $(29 \%)$ of girls with no detectable HAI antibody gave a history of an illness diagnosed as clinical rubella (Table II).

Seventy-three per cent of girls were found to have adequate naturally acquired $\mathrm{HAI}$ antibody titres ranging from 32 to $>256$. Of the initially seronegative and low positive immunized girls, only 17 $(<1 \%)$ had not developed detectable antibodies by two months after administration of vaccine strains of rubella (Table III). While the mean antibody titre for all those with vaccine-induced immunity was lower than that for naturally acquired immunity, antibody titres induced by RA $27 / 3$ strain were higher than those following the Cendehill strain. A number of girls who originally had low HAI antibody titres and were immunized did not have an

TABLE II

RELATION BETWEEN PRESENCE OF RUBELLA HAI ANTIBODIES AND HISTORY OF PREVIOUS CLINICAL RUBELLA

\begin{tabular}{|c|c|c|c|c|c|c|c|}
\hline \multirow{3}{*}{\multicolumn{2}{|c|}{$\begin{array}{c}\text { History of } \\
\text { Rubella }\end{array}$}} & \multicolumn{6}{|c|}{ HAI Titre } \\
\hline & & \multicolumn{2}{|c|}{$<8$} & \multicolumn{2}{|c|}{8 or 16} & \multicolumn{2}{|c|}{$>16$} \\
\hline & & \multirow{2}{*}{$\begin{array}{r}\text { No. } \\
665 \\
107 \\
1,502\end{array}$} & \multirow{2}{*}{$\begin{array}{c}\% \\
29 \cdot 2 \\
4 \cdot 7 \\
66 \cdot 1\end{array}$} & \multirow{2}{*}{$\begin{array}{r}\text { No. } \\
94 \\
13 \\
128\end{array}$} & \multirow{2}{*}{$\begin{array}{c}\% \\
40 \cdot 0 \\
5.5 \\
54 \cdot 5\end{array}$} & \multirow{2}{*}{\begin{tabular}{|l|} 
No. \\
3,389 \\
408 \\
2,925
\end{tabular}} & \multirow{2}{*}{$\begin{array}{r}\% \\
\begin{array}{r}50 \cdot 4 \\
6.1 \\
43.5\end{array}\end{array}$} \\
\hline $\begin{array}{l}\text { Definite } \\
\text { Vague } \\
\text { None }\end{array}$ & $\begin{array}{l}. \\
\therefore\end{array}$ & & & & & & \\
\hline Total & . & 2,274 & $100 \cdot 0$ & 235 & $100 \cdot 0$ & 6,722 & $100 \cdot 0$ \\
\hline
\end{tabular}


TABLE III

COMPARISON OF RUBELLA HAI ANTIBODY TITRES AT 13/14 YEARS FROM PREVIOUS NATURAL INFECTION AND FROM RUBELLA IMMUNIZATION TWO MONTHS BEFORE

\begin{tabular}{|c|c|c|c|c|}
\hline \multicolumn{2}{|c|}{ Source of Immunity } & Total Number & $\begin{array}{l}\text { Number who remained } \\
\text { Seronegative }\end{array}$ & $\begin{array}{l}\text { GMT of HAI Antibody Titre in } \\
\text { Girls with Immunity }\end{array}$ \\
\hline $\begin{array}{l}\text { Natural infection: } \\
\text { HAI titre more than } 1\end{array}$ & 16 & 6,722 & - & 186 \\
\hline $\begin{array}{l}\text { Seronegative vaccinees } \\
\text { Cendehill strain } \\
\text { RA 27/3 strain }\end{array}$ & .. & $\begin{array}{r}941 \\
1,063\end{array}$ & $\begin{array}{r}11 \\
6\end{array}$ & $\begin{array}{r}98 \\
162\end{array}$ \\
\hline $\begin{array}{l}\text { Low positive vaccinees (H } \\
\text { Cendehill strain } \\
\text { RA 27/3 strain }\end{array}$ & 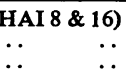 & $\begin{array}{l}108 \\
111\end{array}$ & 二 & $\begin{array}{l}33 \\
38\end{array}$ \\
\hline
\end{tabular}

antibody response; they were considered to be immune. Ten girls had no postimmunization blood test; one had died in an accident and nine could not be traced.

Severe side effects were not common (Table IV), but one-fifth of the girls reported mild symptoms at one to three weeks which they themselves attributed to immunization. A small number of immediate 'reactions' to subcutaneous immunization were also noted. These usually consisted of significant erythema of the upper arm, headache, nausea, and fainting.

One girl was later found to be pregnant at the time of her immunization but she aborted spontaneously. Another girl was diagnosed as having a cerebral tumour two weeks after immunization. Her stay in hospital was complicated by a maculopapular rash four weeks later when rubella HAI antibodiesand no others-were shown to be present. Her cerebral symptoms preceded immunization but had been minimal at that time.

\section{FIRST YeAR OF LONG-TERM Follow-UP}

Of the girls born in 19561,072 have been enrolled in the long-term study. Of these, $479(44 \%)$ had

\section{TABLE IV}

SIDE EFFECTS FOLLOWING RUBELLA IMMUNIZATION WITH CENDEHILL AND RA 27/3 STRAINS OF VACCINE

\begin{tabular}{|c|c|c|c|c|}
\hline \multirow[b]{3}{*}{ Side Effect } & \multicolumn{4}{|c|}{ Vaccine Strain } \\
\hline & \multicolumn{2}{|c|}{ RA 27/3 } & \multicolumn{2}{|c|}{ Cendehill } \\
\hline & No. & $\%$ & No. & $\%$ \\
\hline \multirow{3}{*}{$\begin{array}{l}\text { None } \\
\text { Mild rash, fever, glandis, } \\
\text { headache or vomiting } \\
\text { Severe rash, fever, etc. } \\
\text { and/or arthralgia }, \cdots \\
\text { Immediate reaction'... } \\
\text { No follow-up interview }\end{array}$} & 894 & $75 \cdot 6$ & 838 & $78 \cdot 0$ \\
\hline & 258 & $21 \cdot 8$ & 214 & $19 \cdot 9$ \\
\hline & $\begin{array}{r}6 \\
22 \\
3\end{array}$ & $\begin{array}{l}0.5 \\
1.9 \\
0.3\end{array}$ & $\begin{array}{r}4 \\
12 \\
7\end{array}$ & $\begin{array}{l}0.4 \\
1.1 \\
0.7\end{array}$ \\
\hline Total immunized & 1,183 & $100 \cdot 0$ & 1,075 & $100 \cdot 0$ \\
\hline
\end{tabular}

initially been susceptible to rubella and had been immunized with either the Cendehill vaccine (188 girls) or the RA $27 / 3$ subcutaneous vaccine (291 girls). Forty girls (4\%) with doubtful immunity were immunized with the same vaccines, 25 with the Cendehill and 15 with the RA 27/3. In addition, 17 $(2 \%)$ had no immunity but their parents refused the offer of vaccination, the girls remaining at risk. The number of girls with antibody acquired from natural infection with rubella was 536 (50\%).

Birthday cards and questionnaires have been sent to all girls in the study. At the end of the first year 1,032 girls $(96 \%)$ remained in the study and, of these, $996(97 \%)$ had replied to the initial communication or the first reminder. Of those who remained in the programme, $86(8 \%)$ had changed their address within the year.

A total of 40 girls (4\%) were lost to the study by the end of the first year. Twenty could not be traced by our limited attempts because they had either gone abroad or had moved with no forwarding address; refusals were received from 14 girls, five failed to reply to eight letters, and one had died.

Since the beginning of the study no girls had reported clinical attacks of rubella and no babies had been born to the group of girls involved.

Sera were obtained from 1,031 of the girls one year after their inclusion in the study (Table V). When they were tested in parallel with the previous finger-prick specimen, $958(93 \%)$ had HAI antibody titres that were either stable or within a twofold variation of each other. Forty-seven (5\%) girls showed a fourfold or greater increase in antibody titre in the latest serum sample, the titre in the previous specimen being consistent with the result obtained a year earlier; seven showed a fourfold or greater fall in titre under the same conditions. Of the 47 girls with raised titres, $27(57 \%)$ were vaccinees and all seven of those whose titres had fallen had been vaccinated the previous year. 
TABLE V

RUBELLA HAI ANTIBODY TITRES AT ONE YEAR, 1,031 GIRLS

\begin{tabular}{|c|c|c|c|c|c|c|c|c|c|}
\hline & \multirow[b]{3}{*}{$\begin{array}{l}\text { No. of } \\
\text { Girls }\end{array}$} & \multicolumn{8}{|c|}{ Rubella HAI Antibody Results on Paired Sera } \\
\hline & & \multicolumn{6}{|c|}{ Antibodies present in Initial Serum } & \multicolumn{2}{|c|}{ Antibodies absent in Initial Serum } \\
\hline & & \multicolumn{2}{|c|}{$\begin{array}{c}\text { Stable Titre } \\
\text { or } \times 2 \\
\text { Variation }\end{array}$} & \multicolumn{2}{|c|}{$\begin{array}{l}\times 4 \text { Rise } \\
\text { in Titre }\end{array}$} & $\begin{array}{l}\times 4 \text { Fall } \\
\text { in Titre }\end{array}$ & $\begin{array}{l}\text { Positive to } \\
\text { Negative }\end{array}$ & $\begin{array}{c}\text { Remain } \\
\text { Negative }\end{array}$ & $\begin{array}{l}\text { Convert to } \\
\text { Positive }\end{array}$ \\
\hline \multirow{4}{*}{$\begin{array}{l}\text { Seropositive .. } \\
\text { Cendehill } \\
\text { vaccine } \\
\text { RA 27/3 } \\
\text { vaccine .. } \\
\begin{array}{l}\text { Seronegative } \\
\text { and refused } \\
\text { vaccination }\end{array}\end{array}$} & 512 & 490 & $(94 \%)$ & & $(4 \%)$ & $\mathbf{0}$ & 2 & 0 & $\mathbf{0}$ \\
\hline & 207 & 182 & $(88 \%)$ & 21 & $(10 \%)$ & 1 & 1 & 1 & 1 \\
\hline & 302 & 286 & $(95 \%)$ & 6 & $(2 \%)$ & 6 & 1 & 1 & 2 \\
\hline & 10 & 0 & & 0 & & 0 & 0 & 8 & 2 \\
\hline Total & 1,031 & 958 & $(93 \%)$ & 47 & $(5 \%)$ & 7 & 4 & 10 & 5 \\
\hline
\end{tabular}

Only 10 of the susceptible girls who refused rubella vaccination agreed to join the study. Eight of these girls remained negative but two had acquired immunity from later vaccination.

Of six girls who had been classed as vaccine failures, three had also developed measurable HAI antibody by the end of the first post-vaccination year. Two others remained seronegative and the sixth refused to take part in the long-term programme. Four girls who had previously had low antibody titres in their sera (two vaccinees and two with natural immunity) were found to have become seronegative.

\section{Discussion}

By first screening all the girls, it was possible to reduce the number of those requiring immunization to $27 \%$, a similar proportion to that found in Reading, England (Rowlands and Freestone, 1971). This made it feasible to include a postimmunization blood test which detected the 17 who had no measurable antibody response and who might have erroneously assumed they were immune to rubella.

Girls with immunity due to natural rubella were shown to have higher mean antibody titres than those with antibody induced by rubella vaccine. It was confirmed that a history of clinical rubella was unreliable as a guide to rubella immunity (Just, Bürgin-Wolff, and Ritzel, 1968) and that the incidence of severe side effects induced by immunization was low in girls of this age group (Marshall et al., 1971).

Although the results of only the first year of the long-term study can be reported at present, the stability of rubella HAI antibody (Hillary, 1971) was confirmed by the fact that $93 \%$ of the girls had antibody titres the same as, or within a twofold variation of, the titre found in a serum sample obtained a year earlier. The minor discrepancies of a twofold variation in both directions may, in part, be due to the fact that the previous sample of blood was obtained by a finger-prick and contained only approximately $0.1 \mathrm{ml}$ of serum.

Rubella was known to be present in the community during the year between the taking of the two serum samples. The proportion of girls given RA 27/3 vaccine who showed a fourfold or greater rise in HAI antibody titre (2\%) was less than that for the group with naturally induced immunity. It seemed probable that reinfection with a booster response (Horstmann, 1971) had occurred in both these groups.

It is difficult to know, in this first year after vaccination, whether the higher proportion of those given Cendehill vaccine who showed a fourfold or greater rise in antibody titre $(10 \%)$ arose from a delayed reaction to their vaccination, as was described in previous reports (Fogel et al., 1971; Marshall et al., 1971) or from a greater susceptibility to reinfection (Horstmann, 1971). The latter possibility would be consistent with the fact that those given the Cendehill vaccine originally had a lower mean antibody titre than those who received the RA 27/3 vaccine. All three groups of girls were sharing a similar environment, and the clinical history as reported was not helpful.

Although very few girls had lower antibody titres by the end of the first year of study, this was observed more often in those given RA 27/3 vaccine than in the groups with naturally acquired immunity or with immunity due to Cendehill vaccine. This suggested that the HAI antibody induced by the RA 27/3 vaccine had reached its peak at the time of the first post-vaccination blood test two months after vaccination, and that the titre in a few girls had subsequently begun to fall. Future antibody 
tests will show whether such a reduction in antibody titre is a continuous process, or whether it resembles natural infection, in which an initial fall in HAI titre in the first few months after infection is followed by a long period of time when the antibody titre remains relatively stable.

Cooperation with the schools was good despite the need for three visits each year. The cost of screening and selective immunization was about the same as the cost of mass immunization of all girls in this age group. This programme is being continued, with minor alterations, by the Edinburgh Local Authority School Health Service.

Because there is still uncertainty about the longterm value of rubella immunization (Horstmann, 1971), a valuable feature is that the girls with artificially induced immunity can be identified should re-immunization or booster immunization be recommended.

The response to the 'birthday card' contact technique was better than expected, and it is hoped that at least half of these girls will maintain their interest in the project for the full 20 years, so that the continuing studies on this group of girls will show whether vaccination is as effective as the natural disease in protecting against rubella and against the congenital defects caused by infection in pregnancy.

This work is supported by a grant from the Secretary of State for Scotland (SHHD ref. K/MRS/19C/122) and was carried out under the auspices of the Medical Research Council's Sub-Committee on Rubella Vaccines. The Medical Research Council donated the Cendehill vaccine. The Wellcome Foundation kindly gave an additional grant and all supplies of RA 27/3 vaccine.

I am most grateful to the following for their help: the teachers and girls in all the schools, staff at the Regional Virus Laboratory, City Hospital, Edinburgh, and the Bacteriology Department of Edinburgh University; also to Edinburgh Local Authority school health service, Dr. C. M. P. Bradstreet of the Standards Laboratory, Public Health Laboratory Service, and family doctors throughout the country who sent in specimens of blood.

My thanks are also due to Drs. A. Barnetson, A. Morrison, C. Ramsbottom, M. Spooner, and M. Whitmore, and to Mrs. M. Stewart for their invaluable assistance.

\section{REFERENCES}

Buser, F. and Nicolas, A. (1971). Vaccination with RA 27/3 rubella vaccine. Amer. J. Dis. Child., $122,53$.

DoLD, H. J. and Northrop, R. L. (1968). The nonspecific inhibitors of rubella virus haemagglutination. Proc. Soc. exp. Biol. (N.Y.), 128, 577.

ENDERS J. F. (1970). Leading article. New Engl. J. Med., 283, 261.
Fogel, A., Moshrowitz, A., Rannon, L., and GerichTER, CH.B. (1971). Comparative trials of RA 27/3 and Cendehill rubella vaccines in adolescent and adult females. Amer. J. Epidem., 93, 392.

Hillary, I. B. (1971). Persistence of antibody after subcutaneous vaccination with Wistar RA 27/3 rubella vaccine. J. Hyg. (Camb.), 69, 369.

Horstmann, D. M. (1971). Rubella: The challenge of its control. J. infect. Dis., 123, 640.

Just, M., Bürgin-WolfF, A., and RITZEL, G. (1968). Rubella antibodies in females in Basel. International Symposium on Rubella Vaccines, London. Symp. Series immunobiol. Standard., 11, 25.

McCarthy, K. and TAYLOR-Robinson, C. H. (1967). Aspects of medical virology: rubella. Brit. med. Bull., 23, 185.

Marshall, W. C., Peckham, C. S., Darby, C. P., Dudgeon, J. A., and Hawkins, G. T. (1971). Further studies with rubella vaccines in adults and children. Practitioner, 207, 632.

Martin du Pan, R., Huygelen, C., Peetermans, T., and Prinzie, A. (1968). Clinical trials with a live attenuated rubella virus vaccine. Amer. J. Dis. Child., $115,658$.

Meyer, H. M., Parkman, P. D., Hobbins, T. E., Larson, H. E., Davis, W. J., Simsarian J. P., and Hopps, H. E. (1969). Attenuated rubella viruses: Laboratory and clinical characteristics. Amer. J. Dis. Child., 118, 155.

- - - and Panos, T. C. (1966). Attenuated rubella virus. II. Production of experimental live virus vaccine and clinical trial. New Engl. J. Med., 275, 575.

Parkman, P. D., Buescher, E. L., and Artenstein, M. S. (1962). Recovery of rubella virus from army recruits. Proc. Soc. exp. Biol. (N.Y.), 111, 225.

Plotkin, S. A., Farquhar, J. D., Katz, M., and INGALLS, T. H. (1967). A new attenuated rubella virus grown in human fibroblasts: Evidence for reduced naso-pharyngeal excretion. Amer. J. Epidem., 86, 468.

Prinzie, A., Huygelen, C., Gold, J., Farquhar, J., and MCKeE, J. (1969). Experimental live attenuated rubella virus vaccine. Amer. J. Dis. Child., 118, 172.

Rowlands, D. F. and Freestone, D. S. (1971). Vaccination against rubella of susceptible schoolgirls in Reading. J. Hyg. (Camb.), 69, 579.

Stewart, G. L., Parkman, P. D., Hopps, H. E., Douglas, R. D., Hamilton, J. P., and Meyer, H. M. (1967). Rubella-virus haemagglutination inhibition test. New Engl. J. Med., 276, 554.

Weller, T. H. and Neva, F. A. (1962). Propogation in tissue culture of cytopathic agents from patients with rubella like illness. Proc. Soc. exp. Biol. (N.Y.), 111, 215. 